\title{
The call and rise of disability leaders in Uganda: The first Christian-based bachelors program in disability studies and special education at Africa Renewal University
}

\author{
Ashley A Hall ${ }^{a}$ \\ ${ }^{a}$ Head of Department, Disability Studies and Special Education, Africa Renewal University
}

\section{Introduction}

A residue of rain smacked my face as I withdrew from the airport. It was my first trip to Uganda, and I had the privilege of being a co-leader on a Joni and Friends, Cause 4 Life mission trip, where we served at the Kampala School for the Physically Handicapped $(\mathrm{KSPH})$. The trip included home visits to the families of current students attending KSPH. On a home visit, I embraced a precious mother, Sarah, who had two vibrant boys with Cerebral Palsy. She wept as she divulged her testimony on encountering Jesus Christ through the abuse her two sons endured in various schools throughout Uganda. One particular account had the team teary-eyed as she described how one of her sons came home with a massive welt on the top of his head. "He fell off his chair during class today," expounded the educator after the mother's investigation. Sarah was jaded and revolted from the maltreatment, and perhaps the lies, from the caretakers and teachers. What was a mother to do with her sons who incurred injuries and affliction for years but also needed an education? The mother's face exhibited relief after discussing how God provided a secure establishment for her sons in the current placement at which they were at last, KSPH. For the rest of the families, and much of the world, the anecdote isn't straightforward; many families continue to encounter such afflictions with little resolution.
For a year and a half, I brokenheartedly prayed and sought God for how I could play a vital role in the lives of persons inhabiting Uganda and, more specifically, members who serve persons with disabilities, whether in a small or a large capacity. God said, "Go," and in August of 2014, I moved to Uganda. I ventured out on the undertaking of writing curriculum for a bachelor's degree program at Africa Renewal University. With much trial and tribulation, it was achieved. A Bachelor of Arts in Disability Studies and Special Education (DSSE) was recognized as a legitimate bachelor's degree program from the National Council of Higher Education for the nation of Uganda. More importantly, it has been identified as a bachelor degree program in East Africa that confronts disability from a sound Christian platform. The design of the DSSE program strives to enhance the quality of life for persons and families affected by disabilities by empowering and transforming Christ-like leaders into disability ministry trailblazers. There is a prospect of persons with disabilities becoming productive and active within their societies - a positive, tangible, and potentially historic development.

\section{Facts About Disability in East Africa}

Persons with disabilities are the largest marginalized and unreached sub-group of individuals in the world. The United Nations

Nov 2015. Christian Journal for Global Health, 2(2):52-60. 
reports one billion people in the world with disabilities, and eighty percent of the one billion individuals reside in developing countries. ${ }^{1}$ Uganda, a developing nation, hosts over 6 million people with disabilities. ${ }^{2,3}$ In past and present countries of war, for every child killed in warfare, three are injured and acquire a permanent disability. ${ }^{4}$ As the world remains at war, and, particularly, nations within Africa, the statistic on persons with disabilities surges. Further, more than ninety percent of children with disabilities in developing countries do not attend school, which potentially leads to a mere three percent of literate adults with disabilities globally. ${ }^{5,6}$ Many children and women with disabilities are subjected to violence, rape, abuse, neglect, and other atrocities, for which there is a 1.7 times greater risk than those without disabilities. ${ }^{7,8}$ Around eighty percent of working-age individuals with disabilities residing in developing countries are unemployed. ${ }^{9}$ Finally, access to medical health is exceedingly sparse due to factors such as cost, limited availability, architectural barriers, and inadequate skills in health practitioners, to name a few. Health factors contribute greatly to the continued suffering, sickness, ailments, and high mortality rates in the lives of persons with disabilities in East Africa. ${ }^{1}$ The souls affected by disabilities are facing an epidemic. The disability community remains illiterate, uneducated, unemployed, indisposed, and a target of perilous abuse.

\section{History of Higher Education in Uganda}

There is one university in Uganda, Kyambogo University, which hosts a Special Needs and Rehabilitation Program. The program is composed of three departments: Adult and Community Education, Community and Disability Studies, and Special Needs Studies. The university offers various certificate, diploma, and bachelor level courses. Kyambogo University defines itself as a secular institution. $^{10}$

\section{An Attempt to Identify and Solve}

the Problem: Why a Disability

\section{Studies and Special Education}

\section{Bachelor's Program at Africa}

\section{Renewal University?}

Uganda and East Africa are in a crisis, and that crisis is a shortage of Christian disability ministry leaders in all sectors of the professional field. The DSSE program strives to generate solid Christian disability pioneers by empowering and training them to become special educators, advocates, pastors, caretakers, government officials, social workers, and more. To say that leaders who join the DSSE bachelor's program will solve most of the tragedies throughout Uganda involving persons with disabilities would be an unattainable goal, simply because we live in a fallen world, and the needs of people are many. However, the program seeks to equip leaders to bring transformation into the lives of persons and families with disabilities and attempts to alleviate some of the wounds they are bearing. In addition to the need for leaders, factors such as irrational perspectives, wrongful teaching, the shortfall of compassion in Christians and the Church, the scarcity of higher education programs and training, lack of resources, and the overall absence of an action plan also contributes greatly to the state in which persons and families affected by disabilities are found. These are discussed briefly below.

A few factors in Uganda fashion an unsettled and inadequate educational structure. A discussion of the hurdles in special needs

Nov 2015. Christian Journal for Global Health, 2(2):52-60. 
classrooms and special needs schools produces a familiar account. First, lack of training for educators, particularly special educators, is a recurring problem. Special needs teachers do not feel equipped for their job and the tasks that come along with it. Other factors contributing to the shortage of special educators in Uganda are burn-out rates, lack of pay, scarcity of resources, and overcrowding in the classrooms. This sometimes leads them to venture on to other endeavors instead of remaining in the field. Lastly, before the DSSE program at ARU was implemented, Kyambogo University was the sole university in all of Uganda that provided sound training in special education and disability studies. This brings up the next point, a shortfall of higher education programs overall that equip pioneers for special education and other disability services. Between these pitfalls, special education programs and special educators in Uganda are in a perilous position. There is no doubt that special education in Uganda requires some revamping; this is the reason behind training and empowering scholars in the DSSE program in the area of special education.

Let us not overlook how followers of Christ in East Africa exhibit compassion towards persons with disabilities. Which persons are the last to receive employment, last to be accepted into society, last to be embraced by the Church, last to sense companionship, last to engage in education, last to receive medical attention, and last to experience justice? It is persons with disabilities, and it is evident they are greatly disadvantaged. Christians and the Church are typically distinguished for their tenderness towards sub-groups such as these. However, if we were to investigate the humanity in Christians and the heart of the Church in Uganda, including its role in suffering, what is our status? Why are there so little disability ministries in the churches and communities when persons with disabilities are such a neglected group of individuals? Why are the strained families affected by disabilities receiving little to no Christian guidance and counsel? The answer, in part, is due to misconceptions that are common throughout Uganda and many other parts of Africa. They are the following: people affected by disabilities are cursed by God, their parents sinned in the past so God is punishing them, they do not have enough faith to be healed, or they must be possessed by a demon. ${ }^{11}$ These are some of the chief beliefs that Christians (and other religions) believe in Uganda and East Africa and that are taught throughout the churches. These methods of thinking cause the body of Christ to repel persons with disabilities rather than embrace them. The misconceptions also promote negative attitudes and distorted teaching that all lead to the lack of an action plan for the disability community. Persons and families affected by disabilities are left with little support from the Church and often times feel defeated, humiliated, confused, and/or stigmatized. To presume that the prime dilemma for persons with disabilities throughout the globe is the suffering they undergo would be an understatement. Let's consider the lack of concern for the disability community amongst Christ-like leaders and the Church as an additional affair to tackle. Therefore, the bachelor's of DSSE includes a course, Theology on Suffering and Disability, along with seeing that a Christian worldview is embedded throughout its other courses that address these complications prevalent in Uganda and in the Church.

Other questions to ponder regard the momentous struggles persons and families take on when disability strikes: Where does a parent send their child to be diagnosed or assessed for a disability in a remote village? Where does a family transport a child born with clubfeet for

Nov 2015. Christian Journal for Global Health, 2(2):52-60. 
an operation? How will they obtain the means for the operation and where will they receive the rehabilitation services afterwards? How does a single mother find sustainability when her husband abandons her due to birthing a child with a disability? How does a victim report a crime at a police station that is not wheelchair accessible? How does an injured soul receive medical attention at an inaccessible hospital? What emotional damage does a person boast after being discharged from a church because they were not healed during a miracle service? What rights do adults retain when they have experienced their twentieth job interview and remain unemployed? What parent rights exist when there are no local schools in the village that will welcome or educate their child? What are the repercussions when a staff member pummels a child at school? What is the legal procedure for defending a malnourished or famished child? Where will they find any child protection or social workers to assist with this tragedy? Where do families and individuals go to collect a wheelchair or other assistive devices, averting their loved ones from slithering in the dirt for years and, particularly, a wheelchair or assistive device free or low in cost? Who will fit and size them for the chair? The bachelor of DSSE attempts to lighten some of these unsolved mishaps subsiding in Uganda by educating, equipping, and transforming scholars in the DSSE program.

\section{The Components of the Bachelor in Disability Studies and Special Education at Africa Renewal}

\section{University}

The Bachelor in Disability Studies and Special Education (DSSE) at Africa Renewal University is a 3-year, bachelor degree program, with 120 credit hours. It consists of 23 disability studies and special education courses and 16 general education courses. All DSSE courses require 45 contact hours within a 15week semester system. Each course meets once-a-week for a 3-hour time block. Students are also required to spend approximately 1 to 3 hours, additionally, per week on assignments, projects, and readings per class. The DSSE program seeks to raise up trailblazers for disability ministry in East Africa. The bachelor of DSSE is distinctive in that it promotes Theology on Disability, Disability Ministry, Disability Studies, and Special Education, encompassing a Christian worldview in its entirety. The courses and curriculum coach pioneers to advocate, generate awareness, counsel, evangelize, educate, spearhead initiatives and projects, reform law, and much more for the welfare of families and persons affected by disabilities in East Africa.

\section{Theology on Disability}

The course, Theology on Suffering and Disability, is a 45-hour, 15-week course, with 12 hours specifically geared for the study of theology, suffering, and disability. It provides students with insight on what God and the Bible say about disability, evil and suffering, and spiritual wholeness. This component of the program confronts the common misconceptions about individuals affected by disabilities in Uganda and various global regions, bringing truth and transformation into the hearts of future disability innovators. Topics such as "The Importance of Ministering to People With Disabilities," "Proper Views of Healing," and "The Gospel of Luke: A Framework for Disability" deepens the analysis of theology on disability. ${ }^{12}$ Theology on Suffering and Disability vigorously examines biblical foundations and suffering through the Book of Job, Psalms, Proverbs, the History Books, the Prophets, the Gospels, and The Epistles. Further, these components that make up the

Nov 2015. Christian Journal for Global Health, 2(2):52-60. 
course are also implanted and re-emphasized in other courses throughout the DSSE program as part of Christian worldview feature.

\section{Disability Ministry}

The disability ministry material in the DSSE program covered in the Theology on Suffering and Disability course consists of 2 modules: 1. Overview of Disability Ministry (10 hours) and 2. The Church and Disability Ministry (13 hours). Additionally, subject matter representing a Christian worldview and the Christian response to the minor and major dilemmas in Uganda is discussed throughout the special education and disability studies courses in the DSSE program.

Topics for disability ministry are vast and commence with the Church and the body of Christ. The Church as the cornerstone in disability ministry is stressed in many of the lectures. The study of the Church entails operations and services, the major challenges within and outside the walls, and the responsibility and ownership over the disability community. This also includes an attempt to alter the Church's opposing perceptions regarding ministry for persons and families with disabilities. Pastoral care and disability are not only highlighted to convey the responsibility of God ordained leaders in the Church, but also to underline the level of commitment required from pastors and the body of Christ. The disability ministry material explores methodologies on how to start a disability ministry, along with ministering to and discipling children, teens, adults, and the elderly, and how this ministry can be triumphant. The program exercises diverse outreach and evangelism procedures through assorted domains such as churches, communities, schools, daycare centers, hospitals, villages, recreational outlets, projects and slums, and more. Ideally, this element of the
DSSE program equips disability leaders to incorporate and strengthen friendships with people and families affected by disabilities into their own personal lives, something that often appears novel in East Africa.

\section{Disability Studies}

The Disability Studies component presents an assortment of discourses, debates, and analysis of the historical and contemporary accounts, procedures, and perspectives in Uganda, East Africa, and other regions of the world. The scope of Disability Studies (DS) is vast, and it avoids highlighting solely the identification of characteristics of disabilities, the suffering and circumstances in the lives of the disability community, and other common dilemmas, though they are vital themes examined in the program. Rather, the Disability Studies element features sociological, psychological, holistic, philosophical, biological and medical, and historical foundations that spotlight the perplexities persons with disabilities brave in Africa. Further, the DS component provides 7 courses that examine the livelihood of persons with disabilities that sums up to 315 hours (45 hours each) on critical subject matter for Disability Studies. The courses are as follows: Introduction to Disability Studies; Exceptional People: A Broad Study of Disabilities; Global Perspectives of Disability; History, Policy, and Legislation on Disability; Persons with Disabilities as Portrayed in Film; Legal and Ethical Issues on Disabilities; and Disability, Health, and Wellness. Below are features from one of the courses.

The DS component provides the course, Disability, Health, and Wellness, examining and assessing an array of factors that contribute to the overall health of the disability community. Themes such as nutrition and diet, physical fitness, weight management, stress

Nov 2015. Christian Journal for Global Health, 2(2):52-60. 
management, and even how to create wholesome hobbies and interests are analyzed in this course. In addition, this course explores the common medical ailments such as cuts, abrasions, pressure sores, common sicknesses, and diseases, along with what proper treatment should look like. Other essential topics such as CPR and the utilization and repairing of equipment (i.e., wheelchairs, walkers, prosthetics, etc.) are studied by means of application. Sex education, sexual abuse, sexually transmitted diseases, HIV and AIDS, family planning, and marriage and procreation are also highlighted in this course.

\section{Disability Studies and Special Education}

Exactly 9 courses in the DSSE program, totaling 405 contact hours, represent a little bit of both disability studies and special education subject matter. Physical Disabilities and Physiotherapy; Introduction to Occupational Therapy; Speech Disorders and Speech Therapy; Hearing Impairment and Sign Language; Intermediate Sign Language; Visual Impairment and Braille; Foundations of Autism Spectrum Disorder; Mental Illness and Psychological Disorders; and Community Integration and Vocational Training consist of educational procedures and implications, but also underline societal, medical and biological, historical, Christian based, and/or psychological procedures, approaches, and explanations.

Let us look at the Physical Disabilities and Physiotherapy course as an example. The course has three main components: 1 . Physical Disabilities (6 hours); 2. Educational Considerations (15 hours); and Introduction to Physiotherapy (24 hours). The Physical Disabilities portion studies the definitions, characteristics, features, causes, and prevalence rates of physical disabilities common to East Africa. The Educational Considerations subject matter examines these implications: identifying and diagnosing, assessing and evaluating, progress monitoring, and teaching strategies. Introduction to Physiotherapy section inspects the following: the human body, definitions and vocabulary, exercise, strength training and stretching, preventing and managing physical disabilities and rehabilitation, and assembling and using equipment.

Physical Disabilities and Physiotherapy, along with the other courses mentioned above have been chosen and designed in this manner for several reasons. For one, these courses reflect the realities in which special educators and other practitioners serving in the classrooms and other environments throughout Uganda are expected to deliver these therapies and/or services to their students, even though training and resources are lacking. For example, the majority of special educators or caretakers at a school or day care center have not received adequate training in the "therapies" department, but have many children who are in need of one or all types of therapy services. Often times, the school, organization, and/or business cannot afford to hire therapists. Therefore, the teachers are expected to provide therapy type services to the best of their ability, whether they are trained or not.

Secondly, if a school or organization can afford to hire a physiotherapist or occupational therapist, they may be overwhelmed. An example is the Kampala School for the Physically Handicapped. They have one physiotherapist and one occupational therapist onsite. The current population of students is more than 160. If you divide the therapist's working hours with service delivery sessions, and include other common Ugandan factors that interrupt or delay therapy sessions such as lunches and breaks, rain, injury, sickness, heat, etc., many students end up not receiving sufficient increments of therapy services.

Nov 2015. Christian Journal for Global Health, 2(2):52-60. 
These specific courses are not designed to develop leaders into physiotherapists, occupational therapists, speech therapists, sign language interpreters, etc. Rather, these particular courses are designed to empower scholars in the DSSE program, to educate on the many sectors of therapy services, to expose the challenges between therapies and disability, and to build them up to be well-rounded and skilled disability leaders, meeting the many faceted needs of the disability community.

\section{Special Education}

The Special Education element of the bachelor in DSSE is comprised of six diverse courses equipping pioneers destined for ministry in educational, communal, rehabilitative, and holistic frameworks. There are an additional 6 courses specifically designed for educating persons with disabilities, not including the therapy, visual impairment, and hearing impairment courses. The Special Education element consists of 270 total hours. The following are the courses that make up for the Special Education component: Movement for People with Disabilities; Instructional Planning and Curriculum; Teaching Strategies for Mild to Severe Disabilities; Assessment for Educational and Societal Interventions; Behaviour Management for Children and Youth with Disabilities; and Counseling, Consultation, and Collaboration. Below is a description of one course in the DSSE program that highlights and emphasizes the need for training leaders in the area of physical education.

Movement for People with Disabilities was an addition in the DSSE program to equip future trailblazers for all facets in the Physical Education realm. The course is comprised of three modules: 1. Overview of the Body ( 8 hours); 2. Creating Lessons (12 hours); 3. Student Teaching (25 hours). The Overview of the Body module investigates the skeletal system, muscular system, neurological system, respiratory system, development stages and milestones, and more. The Creating Lessons module studies dance, sports and recreation, dramatics, music, and arts and addresses the procedures and processes in accommodating students and modifying and adapting lessons in order to meet the needs of all students with various disabilities during physical activity happenings. Lastly, the Student Teaching component coaches students on how to write and design actual Physical Education lesson plans, where students will mimic a real educator and perform the actual lesson plan while the other students of the course impersonate themselves as students with different disabilities.

\section{Hopeful Outcomes}

The provision for the bachelor of Disability Studies and Special Education is to bring restoration, hope, and salvation to individuals and families affected by disabilities in the nation of Uganda and other surrounding East African countries by means of equipping disability pioneers. Front-runners will rebuild the body of Christ by generating disability ministries, support groups, bible studies, and community outreaches throughout the churches and communities in Uganda. Uganda will boast special needs or inclusive classrooms where all students can finally engage in vigorous learning. Persons with disabilities could potentially attend and partake in common sporting and recreational events. Rehabilitation centers and hospitals can nurse the disabled with affection, compassion, and integrity. Reformed laws and litigation could flourish as advocates position themselves in the political and governmental spheres, being the voice in the wilderness for the least of these. Perhaps Uganda could offer wheelchair or even

Nov 2015. Christian Journal for Global Health, 2(2):52-60. 
universal accessibility, where persons using assistive equipment can travel and advance to any location without hassle or inconvenience. It is through the humanity, humility, and Christlike intentions of the trailblazers in the DSSE Bachelor program that Uganda may be revolutionized in terms of disability.

\section{Moving Forward and Next Steps}

Africa Renewal University received its first intake of students in September of 2015. All together there were 12 students who joined the program during the first intake. In September of 2016, ARU looks to receive its second batch of students for the program. Each year in September, ARU will offer a new intake. There have been discussions on the probability of adding a night or weekend component to the program for working professionals, but no decisions have been made yet.

Africa Renewal University believes that it is critical for a bachelors program to remain deep-rooted and durable. ARU also believes that East Africans should take up leadership positions and responsibilities within the institution to avoid the long-term presence or operations of an American or person(s) from the West. ARU strives to employ, instruct, mentor, and empower East Africans to carry on projects such as the bachelor of DSSE. Therefore, in January of 2016, ARU will be employing an East African as the Head of Department over the bachelor of DSSE.

\section{References}

1. Disability and health: World Health Organization factsheet [Government report]. Geneva: World Health Organization; [2014 Dec]. Available from http://www.who.int/mediacentre/factsheets/fs352/en/
2. National population and housing census 2014: provisional results [Government report]. Uganda Bureau of Statistics; [2014 Nov]. Available from http://www.ubos.org/onlinefiles/uploads/ubos/NPH C/NPHC\%202014\%20PROVISIONAL\%20RESUL TS\%20REPORT.pdf

\section{Abimanyi-Ochom J, Mannan H. Uganda's} disability journey: progress and challenges. Afri J Dis. 2014;3(1):1-6. http://www.ajod.org/index.php/ajod/article/view/108

4. Disability statistics: facts \& statistics on disabilities \& disability issues [Government report]. Dis World; [2015 July 27]. Available from http://www.disabled-world.com/disability/statistics/

5. EFA flagship initiatives: the right to education for persons with disabilities, towards inclusion [Government report]. United Nations Educational Scientific and Cultural Organization; [n.d.].

Available from http://www.unesco.org/education/efa/know_sharing/ flagship initiatives/persons disabilities.shtml

6. Human development report 1998 [Government report]. United Nations Development Programme; [1998]. Available from http://hdr.undp.org/sites/default/files/reports/259/hdr 1998 en complete nostats.pdf

7. Factsheet on persons with disabilities [Government report]. United Nations Enable; [n.d.]. Available from http://www.un.org/disabilities/default.asp?id=18

8. Crime in England and Wales 2002/2003

[Government report]. Simmons J, Dodd T. 2003. Available from http://webarchive.nationalarchives.gov.uk/2011022010521 0/rds.homeoffice.gov.uk/rds/pdfs2/hosb703.pdf

9. Facts on disability in the world of work Geneva, Switzerland [Government report]. International Labour Organization; [n.d.]. Available from 
http://www.ilo.org/wcmsp5/groups/public/---

dgreports/---

dcomm/documents/publication/wcms_087707.pdf

10. Special needs and rehabilitation [Internet]. Kyambogo University; [n.d.]. Available from http://kyu.ac.ug/index.php/courses/special-needsandrehabilitation
11. Rene J. A global call to reach people with disabilities. In: Beyond suffering: a Christian view on disability ministry. Agoura Hills: Christian Institute on Disability, Joni and Friends International Disability Center; 2011. p. 1-6.

12. Tada J, Bundy S, Verbal P. Beyond suffering: a Christian view on disability ministry. Agoura Hills: Christian Institute on Disability, Joni and Friends International Disability Center; 2011.

Peer Reviewed

Competing Interests: None declared.

Correspondence: Ashley A Hall, Africa Renewal University, Africa. ashleyhall1400@gmail.com

Cite this article as: Hall AA. The call and rise of disability leaders in Uganda, Africa: The first Christianbased bachelors program in disability studies and special education at Africa Renewal University. Christian Journal for Global Health (Nov 2015), 2(2): 52-60.

(C) Hall AA This is an open-access article distributed under the terms of the Creative Commons Attribution License, which permits unrestricted use, distribution, and reproduction in any medium, provided the original author and source are properly cited. To view a copy of the license, visit http://creativecommons.org/licenses/by/3.0/ 